\title{
Breeding activity of Scinax centralis (Anura, Hylidae) in Central Brazil
}

\author{
Mariana B. Alcantara ${ }^{1}$, Leôncio P. Lima ${ }^{1,2}$ \& Rogério P. Bastos ${ }^{1,3}$ \\ 1. Departamento de Biologia Geral, ICB, UFG, Caixa postal 131, 74001-970 Goiânia, Goiás, Brazil. \\ 2. Gerência Executiva, IBAMA, Rua D. Pedro II, 170, 65900-000 Imperatriz, Maranhão, Brazil. \\ 3. Corresponding author. (bastos@icb.ufg.br)
}

\begin{abstract}
From January, 1997 to April, 1998, we studied breeding activity in a population of Scinax centralis Pombal \& Bastos, 1996, in the state of Goiás, inside the Cerrado Biome, Brazil. The behavior of males and females in the choruses, the relationships between environmental variables and the presence of individuals, the spatial distribution pattern, amplexus and clutches were analyzed. The breeding season occurred from November to May. The majority of males began to call when they entered the chorus; they were defending their calling sites against other males. We found a positive correlation between the number of females and males in the choruses, but no significant correlation was observed between the operational sexual ratio (OSR, number of reproducing females/number of reproducing males) and the number of calling males. OSR was highly male-biased; on average, there were 40 males for each female. The presence of individuals was positively correlated with air temperature of two previous days and negatively correlated with rainfall on the observation day. Generally, males were non-randomly distributed and satellite males were observed. Females were larger and heavier than males. Egg number, but not diameter of the egg, was correlated with the female size.
\end{abstract}

KEYWORDS. Scinax centralis, spatial distribution, breeding, aggressive behavior, Central Brazil.

RESUMO. Atividade reprodutiva de Scinax centralis (Anura, Hylidae) no Brasil Central. Entre janeiro de 1997 e abril de 1998 , estudou-se a atividade reprodutiva em uma população de Scinax centralis Pombal \& Bastos, 1996 no estado de Goiás, no bioma Cerrado, Brasil. Analisou-se o comportamento de machos e fêmeas nos agregados reprodutivos, as relações entre variáveis ambientais e a presença de indivíduos, o padrão de distribuição espacial, amplexos e desovas. A estação reprodutiva ocorreu de novembro a maio. A maioria dos machos começou a vocalizar quando entrou nos agregados; defendendo seus sítios de canto contra outros machos. Nós encontramos uma correlação positiva entre o número de fêmeas e de machos presentes no coro, mas não entre a razão sexual operacional (RSO, número de fêmeas reprodutivas/número de machos reprodutivos). A RSO foi altamente desviada para os machos; em média, haviam 40 machos para cada fêmea. A presença de indivíduos foi correlacionada positivamente com a temperatura do ar dos dois dias anteriores e negativamente correlacionada com a chuva do dia da observação. Geralmente, a distribuição espacial dos machos era uniforme. Machos satellites foram observados. As fêmeas eram maiores e mais pesadas que os machos. O número de ovos, mas não o diâmetro, está correlacionado com o tamanho da fêmea.

PALAVRAS-CHAVE. Scinax centralis, distribuição espacial, reprodução, comportamento de agressão, Brasil central.

Most anuran species use vocalizations to mediate social interactions during breeding (WeLLS, 1977; BASTOS \& HADDAD, 1995, 2002). On successive nights, male anurans aggregate in temporary or permanent ponds and emit distinct calls (BEE et al., 2000) because females may use call features as cues for evaluation of the partner fitness (RYAN \& KEDDY-HeCTOR, 1992).

Generally, in the choruses, males greatly outnumber females, so they exhibit territorial behavior which may involves acoustics interactions, postures, and combat (MARTins et al., 1998; BASTOS \& HADDAD, 2002). Males of prolonged or explosive breeding species (sensu WeLls, 1977) may be territorial (ROBERTS, 1994; BASTOS \& HADDAD, 2002). However, territoriality is more accentuated in prolonged breeders because females generally arrive asynchronously in choruses with males (WeLLS, 1977; MuRPHY, 1994).

A consequence of territorial behavior in anurans is the maintenance of a uniform distance between males (ARAK, 1983; Dyson \& PASSMORE, 1992a; BASTOS \& HADDAD, 1999). The maintenance of interindividual distance can reduce the acoustic interference caused by neighbors and may facilitate the location of the calling male by the female (WhitNEY \& KREBS, 1975; DysOn \& PASSMORE, 1992b).

In this paper, we examined the breeding activity of Scinax centralis Pombal \& Bastos, 1996, a small hylid of the $S$. catharinae Boulenger, 1888 group, which is found in gallery forest, one of the physiognomies of the Cerrado biome (Oliveira-Filho \& Ratter, 2002). Primarily, we intend to answer the following questions: (a) What are the relationships between choruses and environmental variables? (b) How are males spatially distributed in choruses? (c) Is there operational sexual ratio bias for males? (d) Are clutches correlated with physical attributes of females?

\section{MATERIAL AND METHODS}

Scinax centralis was observed in a National Forest (FLONA, Floresta Nacional; 1639'32'S; 48³6'29'W) in the municipality of Silvânia, state of Goiás, Brazil, from January 1997 to April 1998. The study area is a patch $(200 \mathrm{~m})$ of rivulet in a gallery forest, with insignificant water flow. Therefore, in the practice, it may be considered (a permanent lentic water body). Field observations were conducted from 17:30 h until 24:00 h or 03:00 h, depending of the activity of the individuals. The studied area was monitored for a total of 178 hours during 41 visits. Meteorological data was provided by a climatological station in FLONA.

The air temperature was recorded with a thermometer to the nearest $0.5^{\circ} \mathrm{C}$. Two hundred forty-five 
males and 16 females were marked by toe clipping (MARTOF, 1953), and measured the snout-vent length (SVL) to the nearest $0.01 \mathrm{~mm}$ with a caliper ruler and weighed individuals to the nearest $0.05 \mathrm{~g}$ with a spring scale. We counted the total number of males and females in the rivulet and recorded the location of these individuals, aggressive interactions, amplexus, and clutches.

In the observed aggressive interactions, we considered a male as a resident when it was calling at the beginning of the focal observations, while the winner was the male that stayed in the call site until the end of the interaction and restarted the vocalization.

All pairs found in amplexus $(\mathrm{N}=11)$ were collected and placed in plastic bags containing water and were maintained until the oviposition. The clutches obtained were preserved in 5\% formalin and the egg diameter was measured with a micrometric ocular. Males and females were weighed and measured as described above, then released alive on the same night.

To analyze the pattern of spatial distribution, we used the methodology of CLARK \& Evans (1954), which considers the distance to the nearest individual and male density at choruses. Data on minimum air temperature and total rainfall of the day or one/two/three previous days of observation were examined to determine their influence on nightly population by stepwise multiple regression forward (ZAR, 1996). We also used the Student's t-test or Pearson correlation coefficient (ZAR, 1996) to analyze and compare the relationship between SVL/ weight of female or male or SVL/weight of female and egg variables. The level of significance considered was 0.05 . Voucher specimens (ZUFG 140-141, ZUFG 174-177) were deposited in the Coleção Zoológica of Universidade Federal de Goiás (ZUFG).

\section{RESULTS}

Calling males of $S$. centralis were first heard in November when the minimum air temperature and humidity were $17.6^{\circ} \mathrm{C}$ and $90 \%$, respectively. Calling stopped completely in August when the minimum air temperature decreased to $9.8^{\circ} \mathrm{C}$ and air humidity to $65 \%$.

Stepwise multiple regression revealed significant positive and negative correlations of the minimum air temperature and of the rainfall of the day or previous days (one/two/three), respectively, with the number of individuals (Tab. I). The strongest coefficient of determination $\left(\mathrm{R}^{2}\right)$ was obtained with the minimum air temperature of the two previous days and rainfall on the observation day. Generally, the coefficient indicated that the variability of the number of individuals in choruses was explained by minimum air temperature and rainfall on the observation day or one/two/three previous day (Tab. I).

The number of males in the chorus was always greater than number of females, which generated low operational sexual ratio (OSR), varying from 0.011 to 0.048 . On average, there were 40 males: 1 female. There was a positive and significant correlation between the number of males and the number of females in the chorus $(\mathrm{r}=0.356$; $\mathrm{P}=0.017 ; \mathrm{N}=41$ ), but not between OSR and number of males $(\mathrm{r}=-0.121 ; \mathrm{P}=0.78 ; \mathrm{N}=12)$.
Table I. Stepwise regression analysis of the environmental variables (air temperature and rainfall) of observation day or one/two/three previous days and number of individuals of Scinax centralis Pombal \& Bastos, 1996. FLONA, Municipality of Silvânia, Goiás, Brazil.

\begin{tabular}{|c|c|c|c|c|c|c|c|}
\hline \multicolumn{2}{|c|}{ Lag day } & \multirow[t]{2}{*}{$\mathrm{R}^{2}$} & \multirow[t]{2}{*}{$\mathrm{F}$} & \multirow{2}{*}{$\mathrm{t}_{\text {air } \mathrm{t}}$} & \multirow{2}{*}{$\mathrm{t}_{\text {rainfall }}$} & \multirow{2}{*}{$\mathrm{P}_{\text {air t }}$} & \multirow{2}{*}{$\mathrm{P}_{\text {rainfall }}$} \\
\hline & ainfall & & & & & & \\
\hline 0 & 0 & 0.466 & 12.6 & 4.17 & -3.78 & 0.0003 & 0.0007 \\
\hline 1 & 0 & 0.482 & 13.5 & 4.34 & -4.21 & 0.0002 & 0.0002 \\
\hline 2 & 0 & 0.556 & 18.1 & 5.17 & -4.33 & 0.0001 & 0.0002 \\
\hline 3 & 0 & 0.503 & 14.7 & 4.57 & -3.80 & 0.0001 & 0.0007 \\
\hline 0 & 1 & 0.203 & 3.69 & 2.64 & -0.06 & 0.0130 & 0.9512 \\
\hline 1 & 1 & 0.167 & 2.91 & 2.33 & 0.19 & 0.0270 & 0.8535 \\
\hline 2 & 1 & 0.269 & 5.35 & 3.20 & 0.18 & 0.0030 & 0.8626 \\
\hline 3 & 1 & 0.257 & 5.01 & 3.09 & 0.20 & 0.0040 & 0.8454 \\
\hline 0 & 2 & 0.238 & 4.54 & 2.96 & -1.16 & 0.0060 & 0.2556 \\
\hline 1 & 2 & 0.200 & 3.62 & 2.64 & -1.11 & 0.0130 & 0.2765 \\
\hline 2 & 2 & 0.309 & 6.48 & 3.55 & -1.30 & 0.0013 & 0.2048 \\
\hline 3 & 2 & 0.291 & 5.96 & 3.41 & -1.21 & 0.0019 & 0.2376 \\
\hline 0 & 3 & 0.222 & 4.15 & 2.65 & 0.85 & 0.0120 & 0.4014 \\
\hline 1 & 3 & 0.180 & 3.17 & 2.27 & 0.70 & 0.0380 & 0.4926 \\
\hline 2 & 3 & 0.290 & 5.93 & 3.24 & 0.94 & 0.0030 & 0.3565 \\
\hline 3 & 3 & 0.276 & 5.51 & 3.11 & 0.89 & 0.0040 & 0.3824 \\
\hline
\end{tabular}

Of the 261 individuals marked between January and May of 1997, none were collected in the following breeding season (November/1997 - April/1998). Females $\left(\overline{\mathrm{X}}_{\mathrm{SVL}}=25.95 \mathrm{~mm} \pm 1.94\right.$, range: $20.85-29.45, \mathrm{~N}=19 ; \overline{\mathrm{X}}_{\text {weight }}=$ $1.02 \mathrm{~g} \pm 0.18$, range: $0.7-1.3, \mathrm{~N}=19)$ were larger $(\mathrm{t}=12.3$, $\mathrm{P}=0.000)$ and heavier $(\mathrm{t}=15.28, \mathrm{P}=0.000)$, after the oviposition, than males $\left(\overline{\mathrm{X}}_{\mathrm{SVL}}=20.31 \mathrm{~mm} \pm 1.06\right.$, range: 17.05-23.45, $\mathrm{N}=243 ; \overline{\mathrm{X}}_{\text {weight }}=0.52 \mathrm{~g} \pm 0.08$, range: $0.3-0.8$, $\mathrm{N}=243)$. There were no significant differences in SVL $(\mathrm{t}=0.74, \mathrm{P}=0.45)$ and weight $(\mathrm{t}=1.17, \mathrm{P}=0.17)$ between males found in amplexus $\left(\overline{\mathrm{X}}_{\mathrm{SVL}}=20.07 \mathrm{~mm} \pm 0.93\right.$, range: $18.5-21.75, \mathrm{~N}=11 ; \overline{\mathrm{X}}_{\text {weigh }}=0.49 \mathrm{~g} \pm 0.06$, range: $\left.0.4-0.6, \mathrm{~N}=11\right)$ and solitary males $\left(\overline{\mathrm{X}}_{\mathrm{SVL}}=20.32 \mathrm{~mm} \pm 1.07\right.$, range: 17.05 $23.45, \mathrm{~N}=232 ; \overline{\mathrm{X}}_{\text {weight }}=0.52 \mathrm{~g}_{ \pm} 0.08$, range: $0.3-0.8, \mathrm{~N}=232$ ).

Males vocalized, generally, on the branches of the marginal vegetation, from $22 \mathrm{~cm}$ above the ground $(\mathrm{SD}=14$ $\mathrm{cm}, \mathrm{N}=80$ ). However, calling males were also observed on the floor or on sticks on the surface of the water. The mean distance observed between neighbor males was $1.7 \mathrm{~m} \pm 2.0$ (range: $0.1-19.4 ; \mathrm{N}=276$ ). A negative correlation was found between chorus size and nearest neighbor distance $(\mathrm{r}=-0.659, \mathrm{df}=12, \mathrm{P}=0.006, \mathrm{~N}=13$; Tab. II). In most of the chorus, the distribution of males was non-random, with an observed uniform pattern in 13 nights (Tab. II).

The males of $S$. centralis were territorial during the breeding activity and defended calling sites with varied degrees of aggressiveness, including acoustic interactions or physical combat. The encounters $(\mathrm{N}=12)$ were always initiated by an intruder with an advertisement call. The resident male answered with territorial calls. Then, the intruder escaped $(\mathrm{N}=6)$ or stayed in a crouched posture $(\mathrm{N}=2)$. However, if the intruder emitted territorial calls near the resident calling male, both males approached each other quickly with short jumps $(\mathrm{N}=4)$. These aggressive interactions last 30 to 90 s, and occasionally up to $3 \mathrm{~min}$. Winner males $\left(\overline{\mathrm{X}}_{\mathrm{SVL}}=20.93 \mathrm{~mm} \pm 1.16,18.8\right.$ $22.05, \mathrm{~N}=6 ; \overline{\mathrm{X}}_{\text {weight }}=0.51 \mathrm{~g} \pm 0.05,0.45-0.60, \mathrm{~N}=6$ ) were not 
Table II. Results of spatial distribution analysis on Scinax centralis Pombal \& Bastos, 1966 individuals in the chorus. FLONA, Municipality of Silvânia, Goiás, Brazil. * Significant to $\mathrm{p} \leq 0.05$; ** Significant to $\mathrm{p} \leq 0.01$

\begin{tabular}{|c|c|c|c|c|c|}
\hline Data & Number of Individuals & $\begin{array}{l}\text { Distance to the closest individual } \\
\qquad \bar{X} \pm \mathrm{DP} \text { (Min - Máx) }\end{array}$ & $\mathrm{R}$ & $\mathrm{C}$ & Interpretation \\
\hline $19 / 02 / 97$ & 64 & $1.76 \pm 1.33(0.25-10.6)$ & 1.83 & $7.61^{* *}$ & Uniform \\
\hline $19 / 03 / 97$ & 40 & $2.44 \pm 1.88(0.10-8.0)$ & 2.178 & $12.57^{* *}$ & Uniform \\
\hline $21 / 03 / 97$ & 46 & $1.12 \pm 0.53(0.40-2.3)$ & 1.49 & $4.20^{* *}$ & Uniform \\
\hline $25 / 04 / 97$ & 31 & $1.94 \pm 1.16(0.40-14.4)$ & 1.87 & $7.75^{* *}$ & Uniform \\
\hline $23 / 05 / 97$ & 17 & $2.64 \pm 0.77(1.90-19.4)$ & 2.28 & $9.15^{* *}$ & Uniform \\
\hline $28 / 12 / 97$ & 40 & $1.36 \pm 0.52(1.0-6.0)$ & 1.72 & $2.75^{* *}$ & Uniform \\
\hline $23 / 01 / 98$ & 85 & $0.74 \pm 0.77(0.20-3.4)$ & 1.09 & 1.00 & Random \\
\hline $22 / 02 / 98$ & 84 & $1.27 \pm 1.06(0.25-3.5)$ & 1.648 & $5.68^{* *}$ & Uniform \\
\hline $20 / 03 / 98$ & 85 & $1.06 \pm 0.81(0.10-3.5)$ & 1.644 & $6.76^{* *}$ & Uniform \\
\hline 03/04/98 & 55 & $1.26 \pm 1.02(0.30-3.5)$ & 2.31 & $11.58^{* *}$ & Uniform \\
\hline 04/04/98 & 54 & $1.14 \pm 0.99(0.20-3.5)$ & 1.62 & $5.91^{* *}$ & Uniform \\
\hline 09/04/98 & 75 & $1.21 \pm 0.95(0.45-3.5)$ & 1.537 & $4.83^{*}$ & Uniform \\
\hline $11 / 04 / 98$ & 60 & $2.08 \pm 1.52(0.15-4.1)$ & 2.24 & $9.51^{* *}$ & Uniform \\
\hline $25 / 04 / 98$ & 45 & $3.07 \pm 0.60(2.2-3.5)$ & 2.43 & $8.31^{* *}$ & Uniform \\
\hline
\end{tabular}

significantly larger $(\mathrm{t}=-1.36, \mathrm{P}=0.25)$ or heavier $(\mathrm{t}=-0.97$, $\mathrm{P}=0.37)$ than losers $\left(\overline{\mathrm{X}}_{\mathrm{SVL}}=19.94 \mathrm{~mm}+1.0\right.$, range: 18.0 $\left.20.9, \mathrm{~N}=6 ; \overline{\mathrm{X}}_{\text {weight }}=0.47 \mathrm{~g} \pm 0.06,0.40-0.55, \mathrm{~N}=6\right)$. We did not observe any aggressive interaction involving females and concluded that they are not territorial.

We also found satellites males $(\mathrm{N}=6)$ that adopted a crouched postured near a calling male. The mean distance between calling and satellite individuals was $27 \mathrm{~cm} \pm 20.66(\mathrm{~N}=3)$. Calling males $\left(\bar{X}_{\mathrm{SVL}}=20.35 \mathrm{~mm} \pm 0.6\right.$, $\left.19.75-21.15, \mathrm{~N}=5 ; \overline{\mathrm{X}}_{\text {weight }}=0.52 \mathrm{~g} \pm 0.04,0.50-0.60, \mathrm{~N}=5\right)$ were not significantly larger $(\mathrm{t}=0.99, \mathrm{P}=0.35)$ or heavier $(\mathrm{t}=1.25, \mathrm{P}=0.21)$ than satellites $\left(\overline{\mathrm{X}}_{\mathrm{SVL}}=19.74 \mathrm{~mm} \pm 1.39\right.$, range: $19.45-21.15, \mathrm{~N}=5 ; \overline{\mathrm{X}}_{\text {weight }}=0.48 \mathrm{~g} \pm 0.07,0.35-0.55$, $\mathrm{N}=5)$. When the calling male was removed, the satellite emitted advertisement calls $(\mathrm{N}=5)$.

We observed the initiation of amplexus twice. A female approximated to the calling male until a distance of $10 \mathrm{~cm}$, staying in front of him and with her body flattened on the substrate. When the male noticed her presence, he stopped the calls and jumped above her without previous physical contact by the female before clasping. The amplexus is axillar and lasted up to 4.5 hours. The clutch was deposited under leaf litter of the rivulet. We did not find a significant correlation between SVL or weight of the males and females in amplexus $\left(\mathrm{r}_{\mathrm{SVL}}=0.549, \mathrm{P}>0.05, \mathrm{~N}=11 ; \mathrm{r}_{\text {weight }}=0.07, \mathrm{P}>\right.$ $0.05, \mathrm{~N}=11)$.

The eggs have a black pigmented animal pole and a cream vegetative pole including a transparent gelatinous layer, being submerged or adhered to the marginal vegetation. Females deposited an average of 64 eggs $\pm 15(\mathrm{~N}=17$ clutches $)$. The egg diameter range from 1.33 to $1.64 \mathrm{~mm}(\bar{X}=1.49 \mathrm{~mm} \pm 0.091)$. We found a significant positive correlation between SVL ( $\mathrm{r}=0.62$, $\mathrm{P}=0.005, \mathrm{~N}=17)$ and weight $(\mathrm{r}=0.61, \mathrm{P}=0.0043, \mathrm{~N}=17)$ of females and the number of eggs by clutch. However, the egg diameter was not correlated with SVL of females $(\mathrm{r}=0.29, \mathrm{P}=0.34, \mathrm{~N}=12)$ and weight $(\mathrm{r}=0.43, \mathrm{P}=0.12, \mathrm{~N}=12)$ or with the number of eggs $(r=0.009, \mathrm{P}=0.85, \mathrm{~N}=12)$.

\section{DISCUSSION}

Our results indicate that Scinax centralis is a typical prolonged breeding species (sensu WELLS, 1977), with individuals congregating at permanent water bodies, where males defend territories and vocalize to attract females, as other anurans (MARTINS, 1988; BAstos \& HADDAD, 1996, 1999; Menin et al., 2004). In the breeding aggregations, the number of males was greater than that of females, arising low nightly estimates of OSRs (40 males: 1 female), as registered in many prolonged breeders (BASTOS \& HADDAD, 1996; 1999; Dyson et al., 1992; WogeL et al., 2002). Low OSR can explain the small number of males $(\mathrm{N}=11)$ encountered in amplexus, because malemale competition (intrasexual competition) is very intense. Otherwise, it is possible that females mate with preferred males.

In addition, the number of males was positively correlated with the number of females, which is a common result in anurans (BASTOS \& HADDAD, 1996; 1999; RICO et $a l ., 2004)$. However, as there was no significant correlation between the number of males and OSR, males in large choruses do not have a higher probability of mating than males in smaller choruses, as observed for other species (BASTOS \& HADDAD, 1996; 1999).

Minimum air temperature and daily rainfall seem to dictate the breeding activity in $S$. centralis, as other species of amphibians (HEATwOle, 1962; SAlvador \& CARRASCAL, 1990; LizANA et al., 1994). As it is expected, the correlation between number of individuals and minimum air temperature was positive because direct insolation generates an increase in soil temperature in the refuge, and the individuals migrate to the breeding area as observed in other species (SALVADOR \& CARRASCAL, 1990). Otherwise, the effect of daily rainfall is negative because they stop the calling activity as verified in other species (e.g. Hyla elegans Wied, 1924, BAstos \& HADDAD 2002).

In this study, we did not recaptured none marked male $(\mathrm{N}=261)$ in the following breeding season. This result may be due to the method of marking by toe clipping, because occasional infections caused the death of 
animals (see Golay \& DurRer, 1994; LEMCKERT, 1996). However, effects of toe-clipping vary among species, with return rates not decreasing (Funk et al., 2005). As the seasonality (dry and rainy seasons) in the Cerrado biome is very intense, it is possible that many individuals died or individuals may have relocated to other patches of rivulet, which were not studied (our study area was only a patch of $200 \mathrm{~m}$ ) and not recaptured. Alternative marking techniques can not be used on the smaller species (as Scinax centralis) and toe clipping is the only efficient method (Funk et al., 2005). So, we can not conclude that toe clipping had some influence on the results.

Males of $S$. centralis showed site fidelity and defended their territories with postures, vocalizations and fights, indicating that the agonistic interactions presented an increasing escalated aggressiveness, this being a similar system found in other species (DysON AND PASSMORE, 1992a; Pombal et al., 1994, Martins et al., 1998; Wogel et al., 2002).

In other anuran species, when aggressive interactions escalate to physical combats, size (HowARD, 1978, RoBERTSON, 1986), residence (Fellers, 1979; WOGEL et al., 2002), or both (Wells, 1978; BASTOS \& HADDAD, 2002) are the main determinant of the result. For $S$. centralis, it is possible that residence was a decisive factor, because the winners of agonistic interactions were always the residents.

An evident consequence of territoriality observed for S. centralis, was the maintenance of a uniform spatial pattern of distribution among males in choruses, as observed for other anuran species (WhITNEY \& KREBS, 1975; Wells, 1977; ARAK, 1983; Bastos \& HadDAD, 1999). The negative correlation between chorus size and nearest neighbor distance found for $S$. centralis is also characteristic of anuran species (GERHARDT et al., 1989; BASTOS \& HADDAD, 1999). However, for S. centralis, the accommodation of additional males into a chorus did not result in alteration of spatial distribution, indicating that males could tolerate a neighbor when the number of individuals in the chorus increased, as observed in other anurans (Wells, 1988). According to Wells (1977), the maintenance of space can reduce the acoustic interference of neighbors therefore, facilitating the location of the calling individual by female, being a compromise between territoriality and mating.

The occurrence of satellite male in S. centralis was registered a few times, making difficult to relate this strategy to population density. However, as we did not find a significant difference between the SVLs of calling and satellite males, and because the satellite male began to emit an advertisement call only when the resident male left, it is possible that the determinant factor that decides between the satellite or calling tactic could be related to the physiological state, as suggested for Dendropsophus minutus (Peters, 1872) (HADDAD, 1991).

Clutch size in S. centralis was positively correlated with weight and SVL of females, as found in other species (BASTOS \& HADDAD, 1996; 1999; Rico et al. 2004). However, in S. centralis the eggs diameter was not correlated with weight or SVL of the females or with the number of eggs by clutch as observed in others anuran species (CRUMP, 1974; RicCO et al., 2004). These last results are not according to Salthe \& Duellman (1973), because expected is a positive correlation between egg diameter and female SVL, or a negative correlation between egg diameter and clutch size.

We conclude that Scinax centralis is a prolonged breeder, with OSR male-biased, with a non-random pattern of spatial distribution, where rainfall and air minimum temperature influences reproductive activity.

Acknowledgements. We would like to thank L.M. Bini and T.F.L.V. Rangel for a critical reading of the manuscript. D.M. Silva and S. Quali for help with English. F.A.A. Oliveira and R.F. Juliano for help with the field work. To Instituto Brasileiro do Meio Ambiente e dos Recursos Naturais Renováveis for permiting us access to the study area. To Centro de Conservação e Manejo de Répteis e Anfíbios (IBAMA/RAN) by license of capture/ transportation. Financial support was provided by Conselho Nacional de Desenvolvimento Científico e Tecnológico (CNPq) and Fundação de Apoio à Pesquisa-UFG (FUNAPE).

\section{REFERENCES}

Abrunhosa, P. A. \& Wogel, H. 2004. Breeding behavior of the leaffrog Phyllomedusa burmeisteri (Anura: Hylidae). AmphibiaReptilia 25:125-135.

ARAK, A. 1983. Vocal interactions, callmatching and territoriality in a Sri Lankan treefrog, Philautus leucorhinus (Rhacophoridae). Animal Behaviour 31:292-302.

Bastos, R. P. \& Haddad, C. F. B. 1995. Vocalizações e interações acústicas de Hyla elegans (Anura, Hylidae) durante a atividade reprodutiva. Naturalia 20:165-176.

1996. Breeding activity of the neotropical treefrog Hyla elegans (Anura, Hylidae). Journal of Herpetology 30:355-360.

1999. Atividade reprodutiva de Scinax rizibilis (Anura, Hylidae) na floresta atlântica, sudeste do Brasil. Revista Brasileira de Zoologia 16:409-421.

2002. Acoustic and aggressive interactions in Scinax rizibilis (Anura: Hylidae) during the reproductive activity in southeastern Brazil. Amphibia-Reptilia 23:97-104.

Bee, M. A.; PerriL, S. A. \& Owen, P. C. 2000. Male green frogs lower the pitch of acoustic signals in defense of territories: a possible dishonest signal of size? Behavioral Ecology 11:169-177.

Clark, P. J. \& Evans, F. C. 1954. Distance to the nearest neighbor as a measure of spatial relationships in populations. Ecology 35:445-453.

Crump, M. L. 1974. Reproductive strategies in a tropical anuran community. Miscellaneous Publications of the Museum of Natural History of the University of Kansas 61:1-68.

Dyson, M. L. \&, PAssmore, N. I. 1992a. Effect of intermale spacing on female frequency preferences in the painted reed frog. Copeia 1992:1111-1114.

1992b. Inter-male spacing and aggression in African painted reed frogs, Hyperolius marmoratus. Ethology 91:237-247.

Dyson, M. L.; Passmore, N. I.; Bishop, P. J. \& Henzi, S.P. 1992. Males behavior and correlates of mating success in a natural population of African painted reed frogs (Hyperolius marmoratus). Herpetologica 48:236-246.

EmLem, S. T. \& Oring, L. W. 1977. Ecology, sexual selection and the evolution of mating systems. Science 197:215-223.

Fellers, G. M. 1979. Aggression, territoriality, and mating behaviour in North American tree frogs. Animal Behaviour 27:107-119.

Funk, W. C.; Donnely, M. A. \& LiPS, K. R. 2005. Alternative views of amphibian toe-clipping. Science 433:193.

Gerhardt, H. C.; Diekamp, B; Ptacek, M. 1989. Inter-male spacing in choruses of the spring peeper, Pseudacris (Hyla) crucifer. Animal Behaviour 38:1012-1024.

Golay, N. \& Durrer, H. 1994. Inflammation due toe-clipping in natterjack toads (Bufo calamita). Amphibia-Reptilia 15:81-96.

Haddad, C. F. B. 1991. Satellite behavior in the Neotropical treefrog Hyla minuta. Journal of Herpetology 25:226-229.

Heatwole, H. 1962. Environmental factors influencing local distribution and activity of the salamander, Plethodon cinereus. Ecology 43:461-472. 
Howard, R. D. 1978. The evolution of mating strategies in bullfrogs, Rana catesbeiana. Evolution 32:850-871.

LeHNER, P. N. 1979. Handbook of ethological methods. New York, Garland STPM. 403p.

LeMCKeRT, F. 1996. Effects of toe-clipping on the survival and behaviour of the Australian frog Crinia signifera. AmphibiaReptilia 17:824-830.

Lizana, M.; Márquez, R. \& Martín-Sánchez, R. 1994. Reproductive biology of Pelobates cultripes (Anura: Pelobatidae) in Central Spain. Journal of Herpetology 28:19-27.

Martins, M. 1988. Biologia reprodutiva de Leptodactylus fuscus em Boa Vista, Roraima (Amphibia: Anura). Revista Brasileira de Biologia 48:969-977.

Martins, M.; Pombal, J. P., JR. \& Haddad, C. F. B. 1998. Escalated aggressive behaviour and facultative parental care in the nestbuilding gladiator frog, Hyla faber. Amphibia-Reptilia 19:65-73.

MARToF, B. S. 1953. Territoriality in the green frog, Rana clamitans. Ecology 34:195-174.

Menin, M.; Silva, R.A. \& Giaretta, A. A. 2004. Reproductive biology of Hyla goiana. (Anura, Hylidae). Iheringia, Série Zoologia, 94(1):49-52.

Murphy, C. G. 1994. Chorus ternure of male barking treefrogs, Hyla gratiosa. Animal Behaviour 48:763-777.

Oliveira-Filho, A. T. \& Ratter, J. A. 2002. Vegetation physiognomies and wood flora of the Cerrado biome. In: Oliveira P. S. \& Marques R. J. (eds.). The Cerrado of Brazil: Ecology and Natural History of a Neotropical Savanna. New York, Columbia University. p. 91-120.

Pombal, J. P., JR.; Sazima. I. \& Haddad, C. F. B. 1994. Breeding behavior of the pumpkin toadlet, Brachycephalus ephippium (Brachycephalidae). Journal of Herpetology 28:516-519.

Rico, M.; Rocha, C. F. D.; Borges, V. N. T. \& Van Sluys, M. 2004. Breeding ecology of Scinax trapicheiroi (Anura, Hylidae) at a creek in the Atlantic rainforest of Ilha Grande, southeastern Brazil. Amphibia-Reptilia 25:277-286.
Roberts, W. E. 1994. Explosive breeding aggregations and parachuting in a neotropical frog Agalychnis saltator (Hylidae). Journal of Herpetology 28:193-199.

RoBERTSON, J. G. M. 1986. Male territoriality, fighting and assessment of fighting ability in the Australian frog, Uperoleia rugosa. Animal Behaviour 34:763-772.

Ryan, M. J. \& Keddy-Hector, A. 1992. Directional patterns of female mate choice and the role of sensory biases. American Naturalist 139(suppl.):4-35.

Salthe, S. N. \& Duellman, W. E. 1973. Quantitative constraints associated with reproductive mode in anurans. In: VIAL J. L. (ed.). Evolutionary biology of the anurans: contemporary research on major problems. Columbia, Univ. Missouri. p. 229-249.

Salvador, A. \& Carrascal, L. M. 1990. Reproductive phenology and temporal patterns of mate acces in Mediterranean anurans. Journal of Herpetology 24:438-441.

Wells, K. D. 1977. The social behaviour of anuran amphibians. Animal Behaviour 25:666-693.

1978. Territoriality in the green frog (Rana clamitans): vocalizations and agonistic behaviour. Animal Behaviour 26:1051-1063.

1988. The effect of social interactions on anuran vocal behavior. In: Fritzsch, B.; Ryan, M. J.; Wilczynski, W.; Hetherington, T. E.; Walkowiak, W. (eds.). The evolution of amphibian auditory systems. New York, John Wiley and Sons. 433-454p.

Whitney, C. L. \& Krebs, J. R. 1975. Spacing and calling in Pacific tree frogs, Hyla regilla. Canadian Journal of Zoology 53:1519-1527.

Wogel, H.; Abrunhosa, P. A. \& Pombal, J. P., JR. 2002. Atividade reprodutiva de Physalaemus signifer (Anura, Leptodactylidae) em ambiente temporário. Iheringia, Série Zoologia, 92(1):57-70.

ZAR, J. H. 1996. Biostatistical analysis. 3rd ed. New Jersey, Prentice-Hall. 662 p.

Recebido em março de 2005. Aceito em abril de 2007. ISSN 0073-4721

Artigo disponível em: www.scielo.br/isz 